\title{
The Socio-Economic and Political Structure of the Peasantry in the Tanzimat Reform Era
}

\author{
Mehmet Devrim Topses ${ }^{a}$
}

\begin{abstract}
Modernization occurs through societies adopting and sustaining reforms that have socio-economic and political implications for individuals of that society. It is impossible for reforms that are ineffective on economic and political lives of large social classes, and that even have negative effects on such lives to achieve a social basis. During the Tanzimat era, although the Ottoman society lacked land ownership, small farmers and agricultural labourers who earned their living from the land served the elite class. In other words, the peasantry was the backbone of the Ottoman society. In this paper, the changes of the socio-economic and political structure of the peasantry were investigated during the modernization of the Tanzimat era during 1839-1876. The research was based on descriptive methods consisting of literature and archive reviews. As a result, although the Tanzimat era has modern civilization characteristics, there were no positive effects on social-economic and political conditions of the peasantry and moreover, the conditions for the peasantry greatly worsened.
\end{abstract}

\section{Keywords}

Social change, Turkish modernization, village sociology, political sociology, social stratification

The Tanzimat reforms are the general name given to the economic and social modernization of the Ottoman Empire during 1839-1876. The important point of these reforms is that nontraditional methods were adopted to find solutions to social problems. Political authority that handles humanitarian and social problems within solid traditional boundaries adopted nontraditional methods for modern requirements. The common objective of the reforms was to sustain social change movements that started at the end of the eighteenth century towards Western civilization. Fundamentally, civilization is a progressive movement. It is due to the fact that civilization gains are not limited to geographical or religious boundaries. Any reform that selects people as a basis, that creates added value, and that protects rights and freedoms is universal. Societies changing according to universal civilization values are expected and necessary. In this way, the Tanzimat era covers change movements towards modern and civilized values based on Ottoman social structure within a political institution.

Although civilization is a necessary and important social action, the Tanzimat era reforms were realized for the benefit of high and powerful classes of the Ottoman Empire. In the nineteenth century, the effort for modernization was invisible in terms of economic and political structure for the peasantry who was the dominant class in Ottoman society. Although the previously mentioned breaking point seemed like a

\footnotetext{
aÇanakkale Onsekiz Mart University, Turkey

Correspondent Author:

Mehmet Devrim Topses, Department of Sociology, Faculty of Arts and Sciences, Çanakkale Onsekiz Mart University, Terzioğlu Campus, Çanakkale, Turkey
} 
thin line, it was strong enough to determine the general success of two hundred years of the modernization efforts of Turkey. In this case, reforms could only shape according to strong social classes just like shaping clay. If needs and expectations of large social classes are ignored and disregarded, social support for the reform movements within the process will lose the impact. The aim of this study is to present economic and political positions of the Ottoman peasantry in the Tanzimat reform era during 1839-1876.

The socio-economic and political positions of the peasantry during the Tanzimat era were investigated under two titles. First, changes in economic relationships during the nineteenth century within Ottoman society and how these changes reflected on the the peasantry were investigated. Capitalized agriculture, tax of the peasantry in new era, relationships between loan shark and government officials, production technologies in villages, and other economic problems of the peasantry were included in the first section. "The political position of the peasantry" investigated the political involvement of the peasantry. Position or prestige of a class in social structure could be measured by identifying involvement in political management. In this section, the question of whether the Tanzimat reforms benefited the peasantry in terms of political involvement was successful or not was addressed. In the same section, certain historical data about the expectations of the peasantry from the Tanzimat reforms were presented. The scope of the paper was limited to 37 years starting from 1839, the official declaration of the Tanzimat mandate, until 1876, the declaring of the First Constitutionalist Period.

\section{SOCIAL AND ECONOMIC CONDITIONS OF THE PEASANTRY}

The social structure of the nineteenth century Ottoman Empire consisted of the peasantry who was small-scale producer or labourer without land. When the Tanzimat was declared, more than $80 \%$ of the population was dependent on land. The majority of this population were peasants who produced to earn their living or who had no land (Quataert 2008: 195). Therefore, when we mention the peasantry, we are talking about the structure of Ottoman society. Taxes collected from the peasantry were the main income of the Ottoman Empire after the eighteenth century. For example, as the debt of the state increased, the tax collection from the production of the peasantry increased four times. In 1873, this corresponded to $44 \%$ of the total treasury income (Findley 2011: 109; Yerasimos 1980: 490). The $70 \%$ of the Ottoman society who lived under the worst conditions were paying $77 \%$ of the total taxes (Yerasimos 1980: 490). If the peasantry refused to pay taxes, collectors or government officials punished them. As Cem (2015: 218) stated, bastinado, tying to a tree, searching the private parts of women for money, and tearing the symbolic money on the head cover of girls were among some punishment methods.

The decisive reason that the economic burden was heavier on the peasantry during the Tanzimat era was the development of foreign trade. However, we are talking about distributing social wealth to foreign trade, which is dependent on imperialism and has comprador structure rather than adopting a new production method that generates wealth (Berkes 1970: 297, 314; Sencer 1969: 82). Individual, small-scale agricultural businesses transformed into large-scale agricultural businesses to supply the raw material needs of developed countries during the industrialisation period. It is clear that this process occurred in two steps. First, the Tanzimat provided a legal assurance for the ownership of masters and beys after the old grooming regime collapsed (Cem 2015: 215). Land legislation in 1858 was a clear example that supported individual property ownership on agricultural lands. Based on this legislation, it is visible that beys and masters who only corresponded 
to $5 \%$ of agricultural class owned approximately $65 \%$ of the land (Yerasimos 1980: 491). After the 1860s, these lands had merged and became large farms that supplied raw material for the foreign market. In this direction, Vilayet-i Umumiye law in 1967 eliminated all the obstacles of capitalist production on land (Aytekin 2015: 51). As the small-scale businesses were eliminated, most of the 950,000 peasantry families had become paid labourers of masters and beys (Yerasimos 1980: 491). Thus, the peasantry who previously only paid taxes to the government was now forced to pay taxes to moneylenders who provided development of large-scale farms for raw material supply.

The subject that should be clearly explained is the new position of tax farming management and tax farmers during the Tanzimat era. Tax farming management was giving the land to private individuals where the tax collected from the peasantry was paid in advance to the government. The peasantry often complained about tax farmers before the Tanzimat period. The reason for this was that tax farmers were aiming to earn the money paid to the government by extensive labour of the peasantry in addition to the taxes collected from the peasantry. Although the Tanzimat mandate forbade tax farming management, tax farmers who bought the right to collect taxes were not eliminated. Tax farmers of the previous period became members of councils in district centres, and continued to be effective in city and village management by adopting different titles (Çadırcı 1997: 37). Tax farmers who controlled agricultural business supervision were sharper and harsher against the peasantry during the Tanzimat era when they planned to increase the profit in trade as well as collecting the taxes (Karpat 2006: 40). The peasantry who tried to make their living as daily labourers was overwhelmed and became indebted even though they worked harder. Various deceptive and relentless methods adopted by tax farmers were indicated by Yerasimos (1980: 490) and Cem (2015: 216) in detail.
Another social reality that concerned the peasantry during the Tanzimat era was inefficient production techniques. Other societies that formed capitalist economic infrastructure had development in production techniques as the peasantry was forced for production. For example, during Meiji reign in Japan in the nineteenth century, although the peasantry worked and lived under harsh conditions, there were advancements in irrigation and fertilization (Güvenç 2010: 237). On the other hand, the Ottoman peasantry was ploughing with wooden ploughs rather than heavy ploughs, using cow dung as fuel rather than fertilizer, and was planting seeds by hand. There were no schools in villages. Daily food often consisted of bread and there were no alternatives other than special celebration days, and this type of diet was insufficient to develop resistance against illnesses (Findley 2011: 110). Engelhardt (2010: 484) who identified the weak conditions of the producer in Ottoman society during the Tanzimat period commented that "there is no such European country where agriculture is prevented short-sightedly by the government that has the most suitable land and climate conditions for agriculture".

Primitive production techniques during the Tanzimat period caused famine and epidemics. The famine was strong which resulted in more than half of the labour population perishing. According to archive records presented by Cem (2015: 221), the peasantry tried to survive by eating dead animal bodies, tree crusts, and plant roots. The peasantry was weak against epidemics and majority of the population died. In addition, the peasantry was collected as soldiers. This situation diminished labour among the peasantry. Secondly, as the peasantry was collected to become soldiers for an indefinite time, nutrition and accommodation during military service were worsening. According to British Admiral Adolphus Slade who worked in the Ottoman army during the Tanzimat period, "...the future of murderers who were sentenced to row was better than the peasantry" (Cem 2015: 222). The most prominent point here is that 
government was unable to protect the peasantry in spite of such social and economic negativities (Engelhardt 2010: 485). As the peasantry was defenceless against oppression and exploitation of tax farmers and loan sharks, they did not receive any help from the government to fight against famine and epidemics. There were no positive regulations during the Tanzimat period that improved the living conditions of the peasantry.

\section{POLITICAL POSITION OF THE PEASANTRY}

The second variable included in this paper is the involvement of the peasantry to political institutions during the Tanzimat period. Thus, it will be clear that whether the Tanzimat period positively affected the peasantry in the Ottoman society in terms of economic and political conditions. After the Tanzimat reforms, municipal councils were established in each city. In reality, involving different social classes in the management organization is innovation in human history. However, according to Ziya Paşa, one of the intellectuals of the period, "...members of the municipality councils in each city were the important people and the old feudal lords of that region" (Karpat 2006: 40). The peasantry was ignored when the municipality councils were established with the help of the Tanzimat reforms. Political instructions oppressed the peasantry, were unable to protect the peasantry against famine and epidemics, and were not listening to the demands of the peasantry. Similar things could also be said for parliamentary reforms that enabled to defend social request against the emperor. All the members of the first Turkish Parliament in 1876 were landowners during the Tanzimat period (Ahmad 2007: 42). It is clear that as the state was closed for the peasantry involvement in politics during the Tanzimat era, the state also insulted and humiliated the peasantry. In the middle of the nineteenth century, there are archive records that recorded oral statements of people who claimed that the peasantry was insulted, beaten, and humiliated in official government institutions (Cem 2015: 219).

The attitude of the peasantry against excluding the peasantry from the Tanzimat reforms is the main problem of the paper. The peasantry faced sharper exploitation on both the economic and political stages compared to the old regime. How could the peasantry become closer to modernization during this period? Engelhardt (2010: 95) stated that the peasantry in the Tanzimat period raised their voices in all appropriate environments to expand the scope of new rights and to benefit from these rights. When the peasantry riots in the nineteenth century were investigated by Aytekin (2015: 40), there were historians who claimed that the peasantry riots during the Tanzimat period were a reaction against reforms and civilization philosophy. According to the author, the peasantry rioted to move the reforms further rather than resisting the Tanzimat. Although the Tanzimat was against their own social profit, if the peasantry really supported the civilization philosophy of the Tanzimat, this would show that the peasantry had revolutionary tendencies rather than conservative ones. The historical scheme in this paper could be summarized as follows.

\section{CONCLUSIONS}

Modern humanitarian values cover the highest values for human rights and freedom in a certain period. Modernization mentions changes in the social structure according to modern society and humanitarian values. In this sense, modernization has progressive properties in terms of principle. The most important discrepancy of the modernization process in Turkey that started in the last period of the eighteenth century was that social classes realized this modernization was dependent on imperialism. Social reforms were shaped by a limited but economically powerful elite class rather than labourers who constituted a larger portion of the society. The Tanzimat period, which could be accepted as one of 
the most distinctive milestones of Turkish modernization, is the clearest example of the above-mentioned process. This paper focused on the relationship between the Tanzimat reforms and the peasantry class, rather than the elite class.

The most prominent property of the peasantry during the Tanzimat period is that the peasantry formed the largest social basis. Therefore, the relationship between the Tanzimat reforms and the peasantry could determine the ideas and thoughts of Turkish society towards modernization from the nineteenth century until today. The results showed that the Tanzimat reforms did not have any positive economic or political effects on the peasantry who was oppressed by the harsh taxes subjected by the state and tax farmers. Moreover, the Tanzimat reforms had a negative impact on the peasantry. Due to the commercialization of agriculture, taxes increased, and the peasantry was defenceless against loan sharks and tax farmers. The state was unable to protect the peasantry against exploitation. While famine and epidemics affected the peasantry largely, the state was unable to offer protection against such negative events. Moreover, the peasantry was humiliated, insulted, and beaten by official government institutions during this period.

Secondly, the political position of the peasantry during the Tanzimat was evaluated. Since the Tanzimat reforms restricted the absolute authority of the sultan against the society, these reforms are progressive. However, as the authority of the sultan was restricted, the political authority of the peasantry did not expand. Political councils established in that period were only beneficial for landowners and important people of the region. Nevertheless, it is interesting that the peasantry objected to reforms that excluded them rather than objecting to reforms themselves. This means that the problem was not caused by the civilization concept, rather it was caused by the peasantry's feeling that the elite class was exploitative. It can be stated that as the peasantry wanted the reforms to be developed to cover themselves as well, this could be a positive process. Besides, the destructive effects of the Tanzimat reforms on social classes who work as labourers, are still visible in the cautious attitude of the modernization process of Turkish society.

\section{References}

Ahmad, F. 2007. The Formation of Modern Turkey. Translated by Y. Alogan. İstanbul: Kaynak Publications.

Aytekin, A. 2015. "At the Junction of Capitalization Center." In Politcal Life in Turkey From Ottoman, edited by G. Atılgan, C. Saraçoğlu, and A. Uslu. İstanbul: Yordam Publications.

Berkes, N. 1970. Turkish Economy History in 100 Questions. İstanbul: Gerçek Publications.

Çadırc1, M. 1997. The Social and Economic Structure of Anotolian Cities in the Tanzimat Period. Ankara: Turkish History Institution.

Cem, İ. 2015. History of Backwardness in Turkey. İstanbul: Turkey Business Bank Publications.

Engelhardt, E.-P. 2010. Modernization Movements in Turkey, the Tanzimat. Translated by Ö.-N. Uğurlu. İstanbul: Örgün Publications.

Findley, C. 2011. Modern Turkish History, Islam, Nationalism and Modernity: 1789-2007. Translated by G. Ayas. İstanbul: Timaş Publications.

Güvenç, B. 2010. Japanese Culture. İstanbul: Boyut Publications.

Karpat, K. 2006. Change in the Ottoman Empire, Modernization. Translated by D. Özdemir. Ankara: İmge Publications.

Quataert, D. 2008. Ottoman Empire: 1700-1922. Translated by A. Berktay. İstanbul: İletişim Publications.

Sencer, M. 1969. Ottoman Society Structure. İstanbul: Ant Publications.

Yerasimos, S. 1980. Turkey in Underdevelopment Process. Translated by B. Kuzucu. İstanbul: Gözlem Publications.

\section{Bio}

Mehmet Devrim Topses, Ph.D., academic member, associate professor, Department of Sociology, Çanakkale Onsekiz Mart University, Turkey; research fields: Turkish modernization, historical materialism, social change. 